\title{
The Status of Interdisciplinary Metaphor in Specialized Lexis
}

\author{
Doina BUTIURCA \\ Sapientia Hungarian University of Transylvania, Cluj-Napoca \\ Faculty of Technical and Human Sciences \\ Department of Applied Linguistics, Târgu-Mureş
}

\begin{abstract}
The assertion we start from in our study is that in specialized languages metaphor is a figure of reason rather than a figure of speech. The general objective of the study is researching the interdisciplinary status of specialized metaphor - terminological and conceptual - by making reference to the hard core of terminology. Derived objectives: comparative research of the degree of scientificity of interdisciplinary metaphor, at the hard core of lexis, following metaphorical transfer; descriptive-linguistic and cognitive research of the general and particular conceptual features that are preserved within this type of internal terminology. The approach is descriptive-contrastive.

One of the conclusions of the research is that the central sphere of specialized lexis, by expansion, supplies terms that may be specialized or may go through a new metaphorical transfer without altering the degree of scientificity in the target fields.
\end{abstract}

Keywords: central sphere, interdisciplinary metaphor, multilingual, terminology

\section{Introduction}

It is unanimously accepted that one of the ways to create terminological metaphors in specialized lexis is the transfer of a term from a source field to a target field. The transfer of specialized terms from one field of knowledge into another is the sine qua non condition in the creation of interdisciplinary terminological metaphor (Rastier 1994: 62-64, Bidu-Vrănceanu 2012: 33-50).

The inner structure of specialized vocabulary is not homogenous, being generally formed from a strongly abstracted ,central sphere” of terms (Sluşanschi 1971), sometimes hermetic, and the external areas made up of heterogeneous subassemblies. The question that arises is: to what extent is the degree of scientificity of interdisciplinary metaphors preserved in the process of transfer from the source 
field to the target field in accordance with the spheres of specialized lexis taken into consideration? Which are the fields where we find general and particular conceptual features preserved in this type of internal terminology?

\section{The relationship between the "hard core" and the feature of "interdisciplinarity" of the specialized metaphor}

As we pointed out on another occasion (Butiurca 2015), conceptual-semantic analysis, etymological analysis as well as the degree of stability of terms may contribute to the relative definition of boundaries between the hard nucleus and migratory terms, usually interdisciplinary - terminological/conceptual metaphors. The central sphere sums up terms and specialized, homogeneous syntagms, which designate a common conceptual background, quasi-universal for each field. The interdisciplinary character of terminology is manifested in various degrees in a field, from a structural perspective. The hard nucleus of philosophy, for example, comprises terms of Greek-Latin, Roman, German, Sanskrit origin, etc., and it is the source of interdisciplinary terminological metaphors in numerous branches of science with illustrations in: the formulation of scientific theories in the broad sense [gestaltism (germ. Gestalt 'structure', 'configuration'), axiology (Gr. axio- 'value' + logos 'word', 'theory'), eidetic (Gr. eidos 'form', 'essence'), entelechy (Gr. enteleheia, from en 'in', telos 'purpose', and enhein 'to have'), epistemic (Gr. episteme 'knowledge', 'science')]; in methodology [heuristic (Gr. eristikos, from erizein 'talk in contradiction'), exoteric (Gr. exoterikos 'exterior' in opposition to esoteric)]; in the language of literary criticism [ataraxia (Gr. $a$ 'without' + 'confusion'), cosmology (Gr. kosmos 'world', 'universe' + logos 'word', 'speech')]; in mathematics [functor (Lat. functus from fungi 'to play a part', 'have a role')]; in logic [deontic (Gr. deon, deontos 'that which is proper', 'which is necessary')]; in the Christian religion [(Chiliasm (Gr. chiliasmos 'one thousand')], etc. Towards the hard nucleus of philosophy, the transference of sense was made, coming independently from religion and Greek-Latin mythology, from the Roman juridical language [a priori (a priori Latin expression for 'that which precedes'), a posteriori (Lat. a posteriori 'that which proceeds')]. Few are the terms belonging to the hard nucleus of philosophy that have not changed their semantic behaviour and their field. Among these, we mention constructs of Sanskrit origin, which designate Oriental religious concepts with a high degree of abstraction: karma (in Sanskrit, 'deed', 'action', 'reward'), nyaya (Sanskrit 'basis', 'conclusion', 'method', 'logic'), veda (Sanskrit 'knowledge', 'science'), etc.

Following the analysis of the hard nucleus of philosophy, we deduce that this represents a source of interdisciplinary metaphors, capable of covering the 
terminological void for concepts belonging to numerous other modern sciences with the exception of socio-political theories. Along the evolution of human thinking, philosophical terms from the central sphere remained ideologically unmarked. Secondly, the transfer occurs only maintaining the abstract degree of re-specialization of the term in the target field, highly scientific as we can see from the examples: (math.) functor - "structures of conservation of categorical relations...”; (log.) functor - logical operator (DEX 1982); (ling.) functor - any word which acquires a syntactic function; (phil.) eidetic is defined in philosophy with "reference to the essence of things" (DEX 1982), while in psychology it means "stemming from imagination" (DEX 1982). The term lemma acquired specific conceptual features in accordance with the field of use: in mathematics, it designates a preliminary or auxiliary mathematical proposition; in logic, it is defined as the premises of a syllogism; lemma, in the broad sense, is a scientific statement of reduced circulation.

The metaphors taken into consideration are migratory terms that maintain a high degree of abstraction without building corresponding metaphoric or metonymic series in the heuristic process of formation of terms/interdisciplinary metaphors.

\section{The semantic features of the interdisciplinary metaphor}

From its formation period, the language of economics imposed itself as an interdisciplinary terminological system (Doina Butiurca 2014) situated at the intersection of two epistemological domains - social sciences and exact sciences. The terminology of economics in the $15^{\text {th }}$ and $18^{\text {th }}$ centuries is characterized by a great power of absorption of the ideological. Realism and "the secularist spirit" in ideology finds its linguistic expression in cognitive constructs such as: mercantile thinking, etatism, hegemonism, etc.

In contemporary economics, the ideological is maintained by multiple pathways, with a terminology adequate to the holistic vision in the Panlatin lexis and/or English: Ro. național (Fr. national; Sp. nacional; En. national; cf. lat natioonis), and its derivatives: Ro. naționalitate (Fr. nationalité; Sp. nacionalidad; En. nationality), Ro. naționalizare (Fr. nationalizasion; Sp. nacionalizacion; En. nationalization), etc.

In the interpretation of interdisciplinary economic constructs from the "central sphere" of terms, we will have in view not only the transfer from one field to another but also an analysis of semantic behaviour in English/partially in Romance languages. On the basis of the terminology of logic and philosophy, the language of economics organizes the paradigms of substance and method in their own 
domain: Ro. formă, a forma un cartel/un consortiu (En. form a cartel/consortium) (Sp. formar un cartel), model (cf. Fr. modèle, Sp. modelo, En. model), Ro. subiect, obiect al proprietății (cf. Fr. objet de propriété// Sp. objeto de propiedad, En. property object) a.s.o. The option is determined by the arbitrariness of the laws of economics, imposed by the variability of contexts and behaviours, the only invariable in the field being diversity.

There are numerous terms from the fields of Physics and Mathematics used in economics by metaphorical transfer. The concepts of mechanism (economic mechanism, price mechanism), fluxes (economic fluxes, real and monetary fluxes), circuit (economic circuit), emergence (emerging economies), force (production forces, workforce, economic force), velocity (velocity of money), acceleration (consumption accelerator), elasticity (elasticity of supply and demand), hysteresis (economic science suffers from hysteresis), and balance (general economic balance) are interdisciplinary metaphorical constructs, fundamental for the paradigms of economic processes in general. Instruments (monetary instruments), levers (price levers), etc. are constructs through which the paradigm of resources is activated.

Insertion/adaptation of mathematical terms and/or terms from the field of physics is achieved by successive formalization and quantification - simultaneous to the constitution of the field of economics on the model of systems and theories. Metaphorical constructs used in Panlatin vocabulary and in English terminology (Skeat W. Walter 2007) which designate taxonomies are varied: sistemul comerțului 'system of commerce', sistemul mercantilist 'mercantile system', teoria cantitativă 'quantitative theory', teoria valorii-muncă 'work-value theory', etc. Ro. centru (cf. Fr. centre// Sp. centro, En. centre// cf. Lat. centrum) is a highly productive interdisciplinary terminological metaphor: Ro. centru comercial (cf. Fr. centre commercial// Sp. centro comercial, En. shopping centre), Ro. centru de cost (cf. Fr. centre du cout// Sp. centro de coste, En. cost centre), Ro. centru de evaluare (cf. Fr. centre d'évaluation// Sp. centro de evaluacion, En. assessement centre). Other terms and/or interdisciplinary metaphors: (a) Ro. formula (Lat. formula, -ae) and its derivatives; Ro. incompatibilitate (cf. Fr. incompatibilité// Sp. incompatibilidad, En. incompatibility); Ro. ordin (cf. Fr. ordre, En. order, Sp. orden, cf. Lat. ordo, -inis) and the terminological units formed by calque after French/English: Ro. ordin de bursă (cf. Fr. ordre de bourse, En. stock exchange order), Ro. regulă (Fr. règle// cf. Lat. regula, -ae): Ro. regula excepțiilor (cf. Fr. règle des exceptions, Sp. regla de las excepciones, En. rule of exceptions); value (Fr. valeur; cf. Lat. valere) - the most productive term created over 50 terminological units in the Panlatin economic language. The conceptual load of economic terms/metaphorical constructs is much more transparent and ensures higher accessibility to users. In the case of the term piață 'market' (cf. It. piazza) - without accessing a definition first -, the speaker creates a naive representation 
of the space where the exchange of goods takes place and relations are established between and among various economic agents, etc. It is a European tradition whose beginnings are found in ancient Rome. Plautus and Horatio used the noun platea (wide street, square) with the meaning of "place of trade", an open space set up for markets, shops, or fairs (forum olitorium, forum vinarium, forum boarium, etc.). We note that piață 'market place' is ab initio a polysemantic word. Univocity of the approximately 30 existing terms in the Panlatin vocabulary is ensured by the compound terminological units/free combinations of words/numerous metaphorical constructs. Semantic and contextual disambiguation allows for the rigorous identification of the specialized denotative meaning. Terminological units thus obtained are accessible, corresponding to the mechanisms of designation that start from the general (piață 'market') to the particular. The term accommodates extensionally by actualizing the concept in the terminological syntagm: material goods and services market, production factors market, spot market, etc.

Metaphorical constructs taken from sports serve as a basis for the scenario of competition: referee, game - economic game, economic actors' game, game of supply and demand, theory of games, zero-sum game, the rules of economic game, etc. The metaphorical language of the competition scenario is interdisciplinary and involves the moral idea, the behaviour of homo oeconomicus.

We observe that structurally interdisciplinary metaphorical constructs are syntagms where the term from the source field is reconceptualized by categorical determinants, nominal indicators that carry some new conceptual features, thus producing fundamental modifications in the semantic behaviour.

The terminological metaphor at the basis of the scenario of resources is money. In international terminology, we find the pair moneda/moneta - the first stemming from Greek while the second coming from Latin. Both forms led to the same metaphorical concept - instrument of payment. The Latin moneta is a semantic derivative of the verb moneo, -ere, -ui, -itum 'recommend', 'warn'. In Latin mythology, moneta was used as an epithet under the acceptation of "advisor" to define one of the attributes of Juno (the mint in Rome was in the temple of Juno Moneta), the term circulating in current Italian economy (It. moneta bassa). French/Panlatin terminology contains approximately 17 metaphorical constructs formed on the model of moneta / monedă comercială (Fr. monnaie commerciale, Sp. moneda comercial - commercial currency); Ro. monedă fără valoare; Ro. monedă din aur şi argint (Fr. monnaie en or et argent, Sp. moneda de oro y plata - gold and silver coin, etc.).

In the denominative process, reinvigoration of specialized vocabulary is made by non-specific, rare, or figurative senses of the classical roots. The English profit (gross earnings) is a Roman derivative of the verb proficio, -ere, -feci, -fectum - utilized in Latin with the sense of walking ahead and, rarely, meaning grow, as used by Plinius (cf. non proficiente pretio). Present-day European economic 
language actualizes the meaning of "excess income obtained by selling of goods made by an economic agent above their cost". The root proficere is very productive, generating in Romance languages and English approximately 10 metaphorical constructs: Ro. profit brut (En. profit/gross earnings, Fr. bénéfice brut, Sp. beneficio bruto), Ro. profit contabil (En. accountancy profit, Fr. profit comptable), etc. The generic metaphor capital (cf. Latin neutral pl. capita 'heads') denotes the concept of "totality of financial resources an enterprise has (money, stocks)", serving conceptually as a basis for approximately 23 terminological metaphors in the language of international business: Ro. capital circulant (Fr. capital actif circulant, It. capitale di circolazione, Sp. capital circulante 'circulating capital'); capital uman (Fr. capital humain, Sp. capital humano, It. capitali umani 'human capital'), etc. The concept is connected to the Roman animal owners' habit to lend a number of "heads".

\section{Conclusions}

Having as main objective the adoption of some new scientific concepts, the interdisciplinary metaphor is conceptual, systematic, or cognitive. Its normative character is conditioned by its appurtenance to a source field and the transfer to a target field in the central sphere of specialized lexis. It is the sphere which gives rise, by expansion, to terms that may be subjected to another specialization or another metaphorical transfer, maintaining the degree of scientificity in the target fields; it must not be mistaken for previous fields.

From a strictly theoretical perspective, the observation imposes itself that in the case of interdisciplinary metaphor semantic modifications are variable in accordance with the semantic average. There are slight modifications, consisting in the addition of features that are specific to the domain - contextually marked, if the semantic average is maintained (as is the case with worn-out metaphors). Semantic modifications may be major, a situation in which metaphorical transfer meets two requirements that are contextually pinpointed - the change of the domain and the alteration of the sense. 


\section{References}

Bidu-Vrănceanu, Angela. (ed.). 2012. Terminologie şi terminologii II. Bucharest: EU. Butiurca, Doina. 2014. Fundamentele lingvistice ale terminologiei economice. Studia Universitatis - Philologia 16: 34-45.

2015. Acomodarea substantivului abstract in terminologie. Studia Universitatis - Philologia 19: 72-77.

Rastier, F. 1994. Semantique pour lanalyse. Paris: Masson.

Skeat, Walter W. 2007. Concise dictionary of English etymology. London: Wordsworth Reference Series.

Sluşanschi, Dan. 1971. Studiul vocabularelor speciale. Studii şi cercetări lingvistice XX: 587-595.

Soskice Martin, J.-Harris.1995. Metaphor in science. In: From a metaphorical point of view - A multidisciplinary approach to the cognitive content of metaphor. Berlin: Radman-N.Y.: de Gruyter.

\section{Dictionaries}

Andrei, N. 1987. Dicționar etimologic de termeni ştiințifici - Elemente de compunere greco-latine. Bucharest: Editura Ştiințifică şi Enciclopedică.

Guțu Gheorghe. 2003. Dicționar latin-român II. Bucharest: Humanitas.

XXXX. 1982. Dicționar explicativ al limbii române. $2^{\text {nd }}$ ed. Bucharest: Editura Academiei Republicii Socialiste România.

XXXX. 2006. Macmillan English Dictionary. International Student Edition. 